Available online at http://journal.stkip-andi-matappa.ac.id/index.php/histogram/index

Histogram : Jurnal Pendidikan Matematika 4(2), 2020, 218-230

\title{
KEMAMPUAN PEMAHAMAN KONSEP ALJABAR DITINJAU DARI METODE PROBLEM SOLVING LEARNING DAN METODE EKSPOSITORI
}

\author{
Rianita Simamora \\ Universitas HKBP Nomensen Medan \\ * Corresponding Author. Email: rianitacharlito@gmail.com \\ Received: 21 Maret 2020; Revised: 15 September 2020 ; Accepted: 30 September 2020
}

\section{ABSTRAK}

Penelitian ini membahas tentang kemampuan pemahaman konsep Aljabar yang ditinjau dari dua motode pembelajaran, yaitu antara problem solving learning dengan ekspositori. Penelitian eksperimen ini menggunakan desain the non-equivalent posttest-only control group design karena kedua kelompok yang akan dianalisis berbeda (non-equivalent). Perlakuan yang diberikan kepada kelompok sampel penelitian ini adalah metode pemecahan masalah (problem solving) dan lainnya menggunakan metode ekspositori. SMA Negeri 3 Pematangsiantar kelas XIPA merupakan populasi yang dipilih dalam penelitian ini yang berjumlah 244 orang dan sebagai sampelnya adalah siswa kelas siswa kelas XIPA-6 dan XIPA-7 yang dipilih menggunakan metode cluster random sampling yang telah dinyatakan normal dan homogen. Instrumen yang digunakan adalah tes essay yang berjumlah 10 butir soal yang valid dan reliabel sehingga layak digunakan sebagai instrumen tes. Penelitian ini menggunakan uji-t (selisih dua rataan) untuk mengetahui perbedaan kedua data penelitian. Hasil penelitian ini menunjukkan bahwa ada perbedaan kemampuan pemahaman konsep aljabar yang signifikan jika ditinjau dari metode problem solving learning dan ekspositori sebagaimana ditemukan dari hasil uji statistik penelitian ini. Perbedaan kedua metode juga ditunjukkan oleh persentase ketuntasan belajar siswa dalam menyelesaikan soal pemahaman konsep.

Kata Kunci: kemampuan berpikir, pemahaman, pemecahan masalah

\section{ABSTRACT}

This study discusses the ability to understand algebraic concepts that are reviewed from two learning mottos, namely between problem solving learning and expository. This experimental study uses the non-equivalent posttest-only control group design because the two groups to be analyzed are different (non-equivalent). The treatment given to this sample group of research is problem solving method and others using expository method. SMA Negeri 3 Pematangsiantar class XIPA is the population selected in this study which amounted to 244 people and as a sample are students of grade XIPA-6 and XIPA-7 students selected using random sampling cluster method that has been declared normal and homogeneous. The instrument used is an essay test that amounts to 10 valid and reliable questions so that it is eligible to be used as a test instrument. This study used t-test (difference of two averages) to determine the difference between the two research data. The results of this study showed that there are significant differences in the ability to understand algebraic concepts when reviewed from problem solving learning and expository methods as found from the results of statistical tests of this study. The difference between the two methods is also shown by the percentage of students' learning completion in solving concept comprehension problems.

Keywords: thinking skills, understanding, problem solving

Copyright $\subset$ 2020, THE AUTHOR (S). This article distributed under the CC-BY-SA-license.

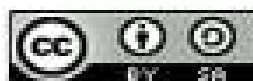




\section{Histogram: Jurnal Pendidikan Matematika, 4 (2), 2020 - 219 Rianita Simamora}

How to Cite: Simamora, R. (2020). Kemampuan Pemahaman Konsep Aljabar Ditinjau Dari Metode Problem Solving Learning Dan Metode Ekspositori. Histogram: Jurnal Pendidikan Matematika, 4(2), 218 - 230, doi: http://dx.doi.org/10.31100/histogram.v4i2.557

Permalink/DOI: http://dx.doi.org/10.31100/histogram.v4i2.557

\section{PENDAhuluan}

Pemahaman konsep merupakan tahapan dasar yang penting dalam serangkaian proses pembelajaran matematika, sebab dengan kemampuan pemahaman konsep, maka setiap individu dapat mengaplikasikasikan prosedur, konsep ataupun proses, serta mengerti hubungan apa yang dipelajari dengan kehidupan nyata. Pemahaman konsep matematika adalah landasan yang penting dalam menyelesaikan persoalan-persoalan matematika yang berkaitan dengan kehidupan sehari-hari.

Pemahaman konsep merupakan aktivitas berpikir meliputi proses memahami, mempelajari, dan mengembangkan ide yang abstrak sehingga dapat menjelaskan sesuatu yang dipahami secara logis, sistematis, koheren, dan benar (Ruseffendi, 1988). Menurut Skemp (1989), pemahaman konsep matematika dinyatakan sebagai proses berpikir melalui aktivitas menggunakan notasi dan simbol matematika sebagai bentuk representasi ide-ide matematika dan upaya mengombinasikan konsep-konsep ke dalam serangkaian penalaran logis. Pemahaman konsep matematika adalah syarat dasar dalam penguasaan ide-ide matematika. Materi-materi baru yang akan dibahas perlu diawali dengan pengenalan konsep dasar, baik terkait konsep yang bersifat induktif maupun yang bersifat deduktif. Memperkenalkan konsep dasar dapat berupa pemberian konsep-konsep yang berkaitan dengan kehidupan sehari-hari atau dapat dikatakan bersifat induktif, sedangkan pengenalan konsep melalui pemaparan konsep, definisi, dan istilah-istilah dikatakan bersifat deduktif.

Setiap konsep yang abstrak dalam matematika perlu dipahami siswa melalui pemberian penguatan sehingga dapat bertahan lama dalam ingatan siswa dan akan terus melekat menjadi pola pikir dan pola tindakannya pada diri siswa (Malay, 2020). Kemampuan memahami konsep pada diri siswa terutama pada topik-topik tertentu dapat dipengaruhi oleh kemampuan memahami konsep terkait topik sebelumnya. Pemahaman konsep yang kuat pada siswa akan membantu dalam mengaitkan serta memecahkan masalah. Berbekal kemampuan dasar terhadap konsep yang telah dipahaminya akan mampu meningkatkan kemampuan berpikirnya hingga mencapai kemampuan berpikir tingkat tinggi. Untuk itu penanaman konsep dasar matematika pada diri siswa perlu dilakukan melalui aktivitas mengaitkan antara materi-

ISSN: 2549-6700 (print), ISSN 2549-6719 (online) 


\section{Histogram: Jurnal Pendidikan Matematika, 4 (2), 2020 - 220 Rianita Simamora}

materi yang diperoleh sebelumnya. Jika siswa tidak menguasai konsep dasarnya dengan benar maka siswa tersebut akan mengalami kesulitan dalam memahami materi selanjutnya.

Ada lima indikator yang menyatakan kemampuan pemahaman konsep matematis siswa, yaitu kemampuan menyatakan ulang konsep, memberi contoh dan bukan contoh, mengklasifikasikan objek-objek, menggunakan dan memilih prosedur tertentu, serta menerapkan konsep dan algoritma perhitungan (Kilpatrick dkk, 2001). Akan tetapi sering kali siswa mengalami kesukaran dalam belajar matematika dikarenakan rendahnya kemampuan matematis yang dimilikinya (Febrinal, 2016).

Kesukaran yang dialami siswa akan tampak ketika siswa tidak mampun mengerjakan soal yang berbeda dengan contoh yang diberikan sebelumnya. Sebahagian besar siswa belajar matematika melalui aktivitas menghafal rumus serta melalui aktivitas mengerjakan soal bersama dengan guru di dalam kelas (Syahlan, 2017). Aktivitas menghafal merupakan strategi yang umum diajarkan dalam menyerap materi namun tidak memiliki arti personal (Langer, 1989; Langer, 2005). Akibatnya siswa akan mendapat kesulitan dalam menyelesaikan soal atau permasalahan non-rutin yang berbeda sangat jauh dengan contoh-contoh yang sering mereka kerjakan bersama dengan guru. Beberapa bentuk soal analisis dan evaluasi yang termasuk dalam kategori kemampuan berpikir tingkat tinggi akan sulit diselesaikan siswa.

Para siswa akan mampu menyelesaikan sebagian besar soal ujian yang berkenaan dengan materi dasar sebagaimana yang telah dicontohkan guru. Namun ketika mereka dihadapkan pada materi dan konteks yang baru, mereka akan mengalami kesulitan akibat hafalan yang mereka lakukan tidak selalu sesuai dengan apa yang diujikan sebagai evaluasi. Aktivitas menghafal tidak akan mampu mengembangkan kemampuan berpikir mereka terutama dalam pemahaman konsep yang pada dasarnya termasuk pada tingkat analisis.

Berdasarkan hasil obervasi terhadap praktek mengajar guru dan wawancara terhadap beberapa guru matematika terkait aktivitas belajar siswa di kelas XIPA SMA Negeri 3 Pematangsiantar, didapat informasi terkait kemampuan pemahaman konsep matematis siswa. Kemampuan memahami konsep siswa secara umum masih jauh dari apa yang diharapkan. Hal ini tampak ketika siswa diberi tugas menyelesaikan soal yang berbeda dengan contoh. Banyak diantara siswa yang tidak mampu menyelesaikan soal yang diberikan, sebagian besar dari siswa tidak mampu menggunakan langkah-langkah prosedur ataupun operasi tertentu dalam menyelesaikan soal yang menjadi tugasnya. Sebagian lagi dari siswa tidak mampu memberikan 


\section{Histogram: Jurnal Pendidikan Matematika, 4 (2), 2020 - 221 Rianita Simamora}

penjelasan tentang konsep materi yang mereka gunakan dalam menyelesaikan soal yang menjadi tugas evaluasinya.

Konsep yang selama ini telah dipelajari siswa tidak serta-merta dapat diaplikasikan kedalam kehidupan mereka. Permasalahan rendahnya kemampuan memahami konsep ini merupakan masalah yang sering dihadapi siswa di dalam kelas. Padahal untuk mampu mencapai kemampuan berpikir tingkat tinggi dibutuhkan kemampuan memahami konsep yang baik, sehingga siswa mampu menyatakan ulang konsep, mengklasifikasikan objek-objek, mengidentifikasi konsep, mengaplikasikan konsep, memberi contoh dan bukan contoh, merepresentasikan ulang konsep dalam bentuk lain, konektivitas berbagai konsep didalam dan diluar matematika, serta mengetahui syarat perlu dan syarat cukup suatu konsep (Permendikbud No. 58 Tahun 2014).

Faktanya, masih sering dijumpai siswa yang kesulitan dalam menyelesaikan permasalahan Sistem Persamaan Linear Tiga Variabel (SPLTV), dikarenakan kurangnya pemahaman konsep matematis siswa tersebut. Hal ini dapat dilihat dari penjajakan awal yang dilakukan peneliti yang memberikan tes awal mengenai Sistem Persamaan Linear Tiga Variabel (SPLTV). Salah satu soal tes yang diberikan dalam penelitian ini adalah sebagai berikut:

“Andi ditugaskan oleh ibunya untuk membeli 3 potong ayam goreng, 2 potong rendang dan 5 potong telur dadar dengan harga Rp. 139.000,00 pada Restoran Bersama. Pada kesempatan lainnya Andi ditugaskan bibinya membeli 2 potong ayam goreng dan 3 potong rendang dengan harga Rp. 106.000,00 untuk makan siang serta membeli 2 potong rendang dan 3 potong telur dadar seharga $R p$. 72.000,00. Menu apakah yang dapat dibeli Andi dengan uang sebesar Rp. 57.000,00? “"

Berdasarkan data dari hasil tes penelitian tersebut diperoleh pada tanggal 26 April 2019 di SMA Negeri 3 Pematangsiantar yaitu pada saat pengamatan awal terhadap indikator pemahaman konsep aljabat terkait sistem persamaan linier tiga variabel (SPLTV) di kelas XIPA yang berjumlah 34 siswa menunjukkan bahwa siswa yang mampu menyatakan ulang suatu konsep ada sebanyak 5,88\% (2 orang), siswa yang dapat menentukan contoh dan bukan contoh ada sebanyak $26,47 \%$ (9 orang) serta siswa yang mampu mengaplikasikan konsep dan algoritma perhitungan dalam pemecahan masalah ada sebanyak 32,35\% (11 orang).

Hasil awal ini mengindikasikan bahwa kemampuan siswa dalam mengungkapkan ide terkait konsep matematis sangat sedikit dikarenakan lebih banyak siswa yang menghafal setiap

ISSN: 2549-6700 (print), ISSN 2549-6719 (online) 


\section{Histogram: Jurnal Pendidikan Matematika, 4 (2), 2020 - 222 Rianita Simamora}

konsep dengan lebih baik. Adapun kemampuan siswa dalam membedakan contoh dan bukan contoh yang secara eksplisit terkandung dalam konsep matematis juga termasuk kategori rendah. Demikian pula dengan kemampuan siswa dalam menggunakan algoritma perhitungan dalam pengaplikasian konsep yang termasuk dalam kategori rendah. Dari ketiga data di atas dapat disimpulkan bahwa kemampuan pemahaman konsep matematis siswa secara umum masih tergolong rendah.

Masalah ini terjadi akibat pembelajaran yang berlangsung di sekolah kurang mengaktifkan siswa untuk memahami konsep. Kebanyakan siswa belajar matematika hanya dengan cara menghafal rumus dan hanya bersumber dari guru saja. Sebagian siswa kurang berkeinginan dalam membangun dan mengembangkan pengetahuan dengan belajar sendiri melalui sumber-sumber lain yang dapat menanamkan pemahaman konsep matematis dalam dirinya. Mereka selalu menanti penjelasan dari guru untuk setiap materi pelajaran. Bahkan, terkadang siswa juga kurang mendengarkan/memperhatikan penjelasan guru, tidak mau mencatat, serta jarang mengajukan pertanyaan. Akibatnya, siswa menjadi pasif dan rendahnya interaksi siswa ke siswa ataupun siswa ke guru. Apabila pembelajaran yang dilaksanakan masih sama dan berjalan sedemikian, maka peneliti menduga bahwa kemungkinan masalah tersebut akan tetap muncul bagi siswa kelas XIPA yang akan datang.

Untuk mengantisipasi masalah tersebut, guru perlu menemukan suatu metode pembelajaran yang dapat membantu siswa dalam meningkatkan kemampuan konsep matematis siswa. Untuk itu, peneliti mencoba metode pembelajaran dengan melibatkan siswa secara aktif (student centered). Salah satunya adalah dengan menggunakan metode pemecahan masalah (problem solving). Pemecahan masalah dapat dijadikan suatu metode pembelajaran yang didasarkan pada aktivitas penemuan kembali (reinvention) untuk memahami materi, menemukan konsep dan prinsip matematika (Sumarmo, 2010).

Aktivitas siswa yang dimulai dengan mengkaji masalah akan menuntun siswa menggunakan sintesa dan/atau analisanya terhadap masalah. Pengetahuan, keterampilan, dan pemahaman yang dimiliki siswa akan menjadi dasar yang kuat dalam menyelesaikan permasalahan yang diberikan. Ini artinya, pembelajaran dengan metode problem solving tidak hanya ditujukan untuk memperoleh pengetahuan saja, tetapi juga untuk membangun keterampilan dan pemahaman terhadap suatu masalah. Metode problem solving akan mengarahkan siswa untuk mengembangkan kemampuan berpikirnya, terutama dalam 


\section{Histogram: Jurnal Pendidikan Matematika, 4 (2), 2020 - 223 Rianita Simamora}

memahami konsep matematis. Metode problem solving ini diharapkan akan lebih baik dibandingkan metode belajar lain dalam hal meningkatkan kemampuan siswa dalam menyelesaikan berbagai soal matematika secara signifikan.

\section{METODE PENELITIAN}

Penelitian eksperimen ini menggunakan desain the non-equivalent posttest-only control group design karena kedua kelompok yang akan dianalisis berbeda (non-equivalent). Perlakuan yang diberikan kepada kelompok sampel penelitian ini adalah metode pemecahan masalah (problem solving) dan yang lainnya menggunakan metode ekspositori. Desain penelitian ini digambarkan sebagai berikut:

Tabel 1 Desain Penelitian Eksperimen

\begin{tabular}{lcc}
\hline Kelompok & Perlakuan & Post-Test \\
\hline Eksperimen I & $\mathrm{A}_{1}$ & $\mathrm{X}_{1}$ \\
Eksperimen II & $\mathrm{A}_{2}$ & $\mathrm{X}_{2}$ \\
\hline
\end{tabular}

Penelitian ini dilakukan di SMA Negeri 3 Pematangsiantar dengan populasi adalah seluruh siswa kelas $\mathrm{X}_{\mathrm{IPA}}$ yang berjumlah 244 orang dengan perincian sebagaimana ditunjukkan pada tabel 2. Adapun yang dijadikan sampel adalah dua kelompok sampel yaitu siswa kelas $\mathrm{X}_{\mathrm{IPA}}-6$ dan $\mathrm{X}_{\mathrm{IPA}}-7$ yang dipilih menggunakan metode Cluster Random Sampling (Lestari \&Yudhanegara, 2017).

Tabel 2 Perincian Jumlah Siswa Kelas $X_{\text {IPA }}$ SMA Negeri 3 Pematangsiantar

\begin{tabular}{ccccccccc}
\hline Kelas & IPA-1 & IPA-2 & IPA-3 & IPA-4 & IPA-5 & IPA-6 & IPA-7 & Jumlah \\
\hline $\begin{array}{c}\text { Jumlah } \\
\text { Siswa }\end{array}$ & 36 & 36 & 35 & 35 & 36 & 34 & 32 & 244 \\
\hline
\end{tabular}

Data penelitian ini didapat dari hasil tes evaluasi pemahaman konsep matematis dari kedua kelompok siswa, yaitu kelas ekperimen I dan II dengan menggunakan instrumen tes yang diberikan pada kedua kelompok sampel. Tes yang digunakan dalam penelitian ini adalah berupa soal-soal tes subjektif berupa uraian (essay) sebanyak 10 soal yang diberikan saat posttest. Pemberian soal posttest ini bertujuan untuk mengetahui ada tidaknya perbedaan 


\section{Histogram: Jurnal Pendidikan Matematika, 4 (2), 2020 - 224 Rianita Simamora}

pemahaman konsep matematis siswa setelah dilakukan pembelajaran dengan menggunakan metode problem solving learning untuk kelas eksperimen I dan metode ekspositori untuk kelas eksperimen II.

Tabel 3 Kisi-kisi Soal Posttest

\begin{tabular}{|c|c|c|c|}
\hline No. & $\begin{array}{c}\text { Indikator } \\
\text { Pemahaman } \\
\text { Konsep }\end{array}$ & Contoh butir tes & $\begin{array}{c}\text { Butir } \\
\text { soal No. }\end{array}$ \\
\hline$\overline{I_{1}}$ & $\begin{array}{l}\text { menyatakan ulang } \\
\text { konsep }\end{array}$ & $\begin{array}{l}\text { Buatlah konsep real (nyata) dari persamaan linier } \\
\text { tiga variabel berikut. } \\
\qquad y=2 x_{1}+\frac{3}{4} x_{2}-4 x_{3}\end{array}$ & 2 \\
\hline $\mathbf{I}_{2}$ & $\begin{array}{l}\text { memberi contoh dan } \\
\text { bukan contoh }\end{array}$ & $\begin{array}{l}\text { Apakah persamaan berikut merupakan persamaan } \\
\text { linier tiga variabel? Berikan penjelasan anda! } \\
\qquad y=2 x_{1}-3 x_{2}^{2}+x_{3}\end{array}$ & 1 \\
\hline $\mathbf{I}_{3}$ & $\begin{array}{l}\text { mengklasifikasikan } \\
\text { objek-objek }\end{array}$ & $\begin{array}{l}\text { Pada bagian mana dari persamaan berikut yang } \\
\text { bukan merupakan persamaan linier: } \\
\qquad y=2 x_{1}-3 x_{2}^{2}+\frac{2}{3} x_{3}\end{array}$ & 3 \\
\hline $\mathbf{I}_{4}$ & $\begin{array}{l}\text { menggunakan dan } \\
\text { memilih prosedur } \\
\text { tertentu }\end{array}$ & $\begin{array}{l}\text { Besarnya gaji dari } 3 \text { orang pegawai adalah sebagai } \\
\text { berikut: } \\
\text { Gaji Burhan sebesar dua kali gaji Haris, gaji }\end{array}$ & 4,5 \\
\hline $\mathbf{I}_{5}$ & $\begin{array}{l}\text { menerapkan konsep } \\
\text { dan algoritma } \\
\text { perhitungan }\end{array}$ & $\begin{array}{l}\text { Bayu lebih Rp. 100.000,00 dari gaji Haris, } \\
\text { sedangkan rata-rata gaji Burhan dan Bayu } \\
\text { adalah Rp. } 950.000,00 . \\
\text { Buatlah model matematika dan nyatakan gaji } \\
\text { masing-masing pegawai tersebut. }\end{array}$ & \\
\hline
\end{tabular}

Uji coba instrumen tes ini dilaksanakan pada hari Kamis tanggal 25 Juli 2019 di SMA Negeri 2 Pematangsiantar kelas $\mathrm{X}_{\mathrm{IPA}}-6$ yang dinyatakan homogen dengan sampel penelitian ini sebagai sampel ujicoba butir tes untuk menghindari kebocoran instrumen sebelum digunakan. Uji coba dilakukan untuk mengetahui kualitas tes yakni melalui validitas butir tes, reliabilitas butir tes, daya pembeda butir tes, dan tingkat kesukaran butir tes. Hasil pengujian menunjukkan bahwa semua butir tes telah memenuhi kriteria dan dinyatakan valid. Adapun nilai koefisien ISSN: 2549-6700 (print), ISSN 2549-6719 (online) 


\section{Histogram: Jurnal Pendidikan Matematika, 4 (2), 2020 - 225 Rianita Simamora}

reliabilitas butir tes tersebut adalah sebesar 0,666 sehingga disimpulkan bahwa butir tes tersebut adalah reliabel. Adapun nilai indeks daya pembeda dari setiap butir tes serta nilai indeks kesukaran butir tes dinyatakan sebagai berikut.

Tabel 4 Indeks Daya Pembeda dan Indeks Kesukaran Butir Tes

\begin{tabular}{ccccc}
\hline $\begin{array}{c}\text { No. } \\
\text { Item }\end{array}$ & $\begin{array}{c}\text { Daya } \\
\text { Pembeda }\end{array}$ & Keterangan & $\begin{array}{c}\text { Indeks } \\
\text { Kesukaran }\end{array}$ & Keterangan \\
\hline $\mathbf{1}$ & 0,469 & Baik & 0,682 & Sedang \\
$\mathbf{2}$ & 0,250 & Cukup & 0,718 & Mudah \\
$\mathbf{3}$ & 0,266 & Cukup & 0,404 & Sedang \\
$\mathbf{4}$ & 0,469 & Baik & 0,682 & Sedang \\
$\mathbf{5}$ & 0,469 & Baik & 0,682 & Sedang \\
$\mathbf{6}$ & 0,469 & Baik & 0,682 & Sedang \\
$\mathbf{7}$ & 0,250 & Cukup & 0,700 & Sedang \\
$\mathbf{8}$ & 0,210 & Cukup & 0,700 & Sedang \\
$\mathbf{9}$ & 0,210 & Cukup & 0,700 & Sedang \\
$\mathbf{1 0}$ & 0,312 & Cukup & 0,696 & Sedang \\
\hline
\end{tabular}

Berdasarkan tabel 4 di atas diketahui bahwa indeks daya pembeda setiap butir tes berada dalam kategori cukup sedangkan nilai indeks kesukaran butir tes termasuk dalam kategori sedang dan hanya ada satu soal yang termasuk kategori mudah. Untuk itu, peneliti memilih lima butir tes yaitu 1, 4, 5, 6, dan 10 untuk dijadikan instrumen tes pemecahan masalah dalam penelitian ini.

\section{HASIL DAN PEMBAHASAN}

\section{A. Hasil Penelitian}

Hasil uji yang dilakukan menggunakan butir soal posttest yang telah dinyatakan valid, reliabel serta mencukupi nilai indeks daya pembeda serta dengan indeks kesukaran tingkat sedang. Adapun data hasil pengujian posttest terhadap kedua kelompok sampel ditunjukkan oleh tabel 5 berikut. 


\section{Histogram: Jurnal Pendidikan Matematika, 4 (2), 2020 - 226 Rianita Simamora}

Tabel 5 Nilai Posttest Siswa Kedua Kelompok Sampel

\begin{tabular}{|c|c|c|c|c|}
\hline \multirow{2}{*}{ Jenis Statistik } & \multicolumn{2}{|c|}{ Kelas Eksperimen I } & \multicolumn{2}{|c|}{ Kelas Eksperimen II } \\
\hline & Interval & Frekuensi & Interval & Frekuensi \\
\hline \multirow{5}{*}{$\begin{array}{l}\text { Distribusi } \\
\text { Frekuensi }\end{array}$} & $70-71$ & 5 & $48-49$ & 6 \\
\hline & $72-73$ & 4 & $50-51$ & 5 \\
\hline & $74-75$ & 6 & $52-53$ & 5 \\
\hline & $76-77$ & 15 & $54-55$ & 11 \\
\hline & $78-79$ & 4 & $56-57$ & 5 \\
\hline n (sampel) & \multicolumn{2}{|c|}{34} & \multicolumn{2}{|c|}{32} \\
\hline rataan & \multicolumn{2}{|c|}{75,00} & \multicolumn{2}{|c|}{52,75} \\
\hline varians & \multicolumn{2}{|c|}{7,21} & \multicolumn{2}{|c|}{7,42} \\
\hline Std. dev. & \multicolumn{2}{|c|}{2,68} & \multicolumn{2}{|c|}{2,72} \\
\hline
\end{tabular}

(Sumber: Data Primer, 2019)

Tabel 5 di atas menunjukkan adanya perbedaan diantara kedua kelompok sampel baik dari segi nilai rataan maupun skor yang diperoleh. Namun belum dapat menentukan apakah kedua data di atas adalah berbeda secara signifikan. Untuk itu, perlu dikaji lebih lanjut dengan menggunakan uji selisih dua rataan setelah kedua data dinyatakan normal dan homogen. Berdasarkan perhitungan terhadap data kelompok eksperimen diperoleh harga $\mathrm{L}_{0}$ adalah $0,1195<\mathrm{L}_{\text {tabel }}$ yaitu 0,152 (untuk $\mathrm{n}=34$ dan $\alpha=0,05$ ) sehingga disimpulkan bahwa data sampel kelompok eksperimen berdistribusi normal. Adapun untuk kelompok kontrol didapat nilai $\mathrm{L}_{0}$ adalah $0,0938<\mathrm{L}_{\text {tabel }}$ yaitu 0,156 (untuk $\mathrm{n}=32$ dan $\alpha=0,05$ ) sehingga disimpulkan bahwa data sampel kelompok kontrol juga berdistribusi normal.

Adapun untuk mengetahui apakah kedua data berasal dari sampel yang homogen digunakan uji $\mathrm{F}$ satu pihak dimana nilai titik-titik kritis $\mathrm{F}_{\text {hitung }}$ sebesar 1,0291 $<\mathrm{F}_{0,05 ; 33 ; 31}$ yaitu 1,85165 sehingga disimpulkan bahwa kedua sampel berasal dari populasi dengan varians sama atau homogen. Oleh sebab itu, maka dapat dinyatakan bahwa kedua data telah memenuhi uji persyaratan data sehingga dapat menggunakan uji statistika parametrik.

Hasil perhitungan untuk uji selisih dua rataan kelas eksperimen (metode problem solving) didapat $\mathrm{t}_{\text {hitung }}$ sebesar $33,636<\mathrm{t}_{\text {tabel }}(0,975 ; 64)$ yaitu 2,001 yang ternyata $\mathrm{t}_{\text {hitung }}$ berada pada daerah kritik yang artinya bahwa rataan hasil pemahaman konsep matematis kedua sampel 


\section{Histogram: Jurnal Pendidikan Matematika, 4 (2), 2020 - 227 Rianita Simamora}

berbeda secara signifikan. Kesimpulan yang didapat menunjukkan adanya perbedaan yang signifikan antara pemahaman konsep matematis siswa yang diajar menggunakan metode problem solving learning dengan metode pembelajaran ekspositori pada materi Aljabar, yaitu Sistem Persamaan Linear Tiga Variabel (SPLTV) di kelas XIPA SMA Negeri 3 Pematangsiantar T.A 2019/2020.

Pada pembelajaran pemecahan masalah (problem solving) diketahui bahwa rata-rata kemampuan pemahaman konsep matematis siswa berada dalam kategori baik sedangkan nilai rata-rata kemampuan pemahaman konsep matematis siswa pada pembelajaran ekspositori berada dalam kategori rendah. Banyak siswa yang menjawab soal berdasarkan Indikator-1, 2, 3 dan 5 pada metode problem solving learning lebih tinggi jika dibandingkan nilai siswa dengan metode ekspositori (94\%; 53\%; 92\%; 91\% <66\%; 27\%; 59\%; 61\%). Adapun berdasarkan Indikator-4: pada metode problem solving learning sama dengan nilai siswa dengan metode ekspositori (73\%).

Tabel 6 Persentase Ketuntasan Siswa Berdasarkan Indikator Pemahaman Konsep

\begin{tabular}{lcc}
\hline \multicolumn{1}{c}{ Indikator Pemahaman Konsep } & $\begin{array}{c}\text { Metode } \\
\text { problem solving } \\
\text { learning }\end{array}$ & $\begin{array}{c}\text { Metode } \\
\text { ekspositori }\end{array}$ \\
\hline $\mathrm{I}_{1}$ : menyatakan ulang konsep & $94 \%$ & $66 \%$ \\
$\mathrm{I}_{2}$ : memberi contoh dan bukan contoh & $53 \%$ & $27 \%$ \\
$\mathrm{I}_{3}$ : mengklasifikasikan objek-objek & $92 \%$ & $59 \%$ \\
$\mathrm{I}_{4}$ : menggunakan dan memilih prosedur tertentu & $73 \%$ & $73 \%$ \\
$\mathrm{I}_{5}$ : menerapkan konsep dan algoritma perhitungan & $91 \%$ & $61 \%$ \\
\hline
\end{tabular}

(Sumber: Data Primer, 2019)

\section{B. Pembahasan}

Perbedaan kemampuan pemahaman konsep yang ditemukan pada penelitian ini dapat disebabkan oleh perbedaan aktivitas belajar dimana pada metode problem solving learning siswa dapat membangun pengetahuannya terhadap konsep matematika melalui aktivitas mengamati karakteristik-karakteristik objek matematika serta adanya aktivitas percobaan yang dilakukan siswa baik secara sendiri maupun berkelompok. Hasil penelitian yang sama juga telah dinyatakan sebelumnya oleh Arifah dan Saefudin (2017) yang mengungkapkan bahwa ISSN: 2549-6700 (print), ISSN 2549-6719 (online) 


\section{Histogram: Jurnal Pendidikan Matematika, 4 (2), 2020 - 228 Rianita Simamora}

metode ekspositori pada prinsipnya adalah berupa aktivitas penyelesaian soal secara bersamasama sehingga pemahaman konsep yang dimiliki siswa termasuk dalam kategori sedang.

Data pada penelitian ini juga menunjukkan bahwa rata-rata pemahaman konsep matematis siswa dan persentase ketuntasan belajar siswa melalui metode problem solving learning lebih tinggi daripada pembelajaran konvensional maupun ekspositori. Hal ini menurut Rahmawati, Noer, dan Coesamin, (2013) adalah disebabkan oleh adanya perbedaan aktivitas belajar siswa sehingga terdapat lebih dari $60 \%$ siswa yang mengikuti metode problem solving learning tuntas dalam belajarnya.

Metode problem solving learning juga mampu mendorong aktivitas siswa untuk terlibat dan membawa motivasi kepada siswa untuk memperoleh pemahaman yang mendalam tentang topik-topik yang diajarkan. Siswa dapat membangun pemahamannya terhadap satu konsep melalui aktivitas pengamatan terhadap karakteristik-karakteristik objek matematikanya. Aktivitas yang dilakukan siswa dapat tertanam lebih lama dan membentuk kemampuan berpikirnya lebih baik dalam memperoleh rumus/konsep matematika (Arifah dan Saefudin, 2017).

Pada saat proses pembelajaran sebaiknya siswa diperkenalkan dengan berbagai latihan soal pemahaman konsep yang menyeluruh dan merata sehingga siswa akan terbiasa (Afifah, 2019) sebagaimana yang telah dilakukan dalam metode problem solving learning. Pembelajaran Matematika yang mengacu pada pemahaman konsep sebaiknya dilakukan dengan menggunakan bahasa nstruksional yang jelas, menekankan pada pengajaran konsep ketimbang algoritma, membantu siswa menghubungkan setiap konsep yang dimiliki (Molina, 2014) sebagaimana yang dilakukan siswa dalam proses pembelajaran dengan metode problem solving. Menggunakan prosedur singkat yang umum dilakukan dalam berbagai buku matematika sehingga memungkinkan adanya pemahaman yang mendalam terhadap konsep matematika yang disajikan (Mulyono dan Hapizah, 2018) sehingga tugas guru adalah membantu siswa dalam membangun keterampilan berpikir yang dibutuhkan untuk perubahan dan inovasi.

\section{KESIMPULAN DAN SARAN}

\section{A. Kesimpulan}

Untuk dapat meningkatkan kemampuan pemahaman konsep matematis siswa dan menjadikannya lebih baik lagi adalah dapat melalui penerapan metode problem solving. 


\section{Histogram: Jurnal Pendidikan Matematika, 4 (2), 2020 - 229 Rianita Simamora}

Melalui metode problem solving, siswa akan dapat berperan aktif lebih baik dalam pembelajaran sehingga akan meningkatkan motivasi untuk mempelajari materi dan konsep yang diajarkan lebih baik lagi jika dibandingkan dengan menerapkan metode ekspositori.

\section{B. Saran}

Sehubungan dengan kesimpulan penelitian di atas, maka disarankan kepada para guru untuk menerapkan metode problem solving untuk membantu meningkatkan kemampuan pemahaman konsep matematis siswa.

\section{DAFTAR PUSTAKA}

Afifah, R. (2019). Analisis Profil Proses Kognitif Pemahaman Konsep Siswa. JPF: Jurnal Pendidikan Fisika Universitas Muhammadiyah Metro, 7 (2), September 2019.

Arifah, U., dan A.A. Saefudin. (2017). Menumbuhkembangkan Kemampuan Pemahaman Konsep Matematika dengan Menggunakan Model Pembelajaran Guided Discovery. NION: Jurnal Pendidikan Matematik, 5 (3), November 2017.

Febrinal, D. (2016). Peningkatan Kemampuan Komunikasi Matematis Melalui Contextual Teaching Learning (CTL) Di Kelas VIII SMP 44 Sijunjung. Jurnal Kepemimpinan Dan Pengurusan Sekolah, 1(2), 181-192.

Kilpartick dkk. (2001). Adding it up: Helping Children Learn Mathematics. Washington DC: National Research Council.

Langer, E. J. (1989). Mindfulness. Cambridge, MA: Perseus Books Group.

Langer, E. J. (2005). On becoming an artist: Reinventing yourself through mindful creativity. New York: Ballantine Books.

Lestari, K.E., dan M.R. Yudhanegara. (2017). Analisis adaptive reasoning proficiency mahasiswa melalui implementasi teori conditioning-reinforcement-scaffolding (CRS) pada mata kuliah analisis real. Jurnal Penelitian Pendidikan dan Pengajaran Matematika, 3 (2).

Malay, I. (2020). Pendekatan Matematika Realistik sebagai Upaya Meningkatkan Kemampuan Pemecahan Masalah Siswa Tingkat SMP. MES: Journal of Mathematics Education and Science, 5 (2).

Molina, C. (2014). Teaching mathematics conceptually. SEDL insights, 1(4), 1-8

Mulyono, B., dan Hapizah. (2018). Pemahaman Konsep dalam Pembelajaran Matematika. KALAMATIKA: Jurnal Pendidikan Matematika, 3 (2), November 2018 . 


\section{Histogram: Jurnal Pendidikan Matematika, 4 (2), 2020 - 230 Rianita Simamora}

Pemerintah, R.I. (2014). Peraturan Menteri Pendidikan dan Kebudayaan Nomor 58 Tahun 2014 tentang Kurikulum 2013 Sekolah Menengah Pertama/Madrasah Tsanawiyah. Jakarta: Kementerian Pendidikan dan Kebudayaan.

Rahmawati, A.D., S.H. Noer, dan M. Coesamin. (2013). Efektivitas Penerapan Metode Penemuan Terbimbing terhadap Kemampuan Pemahaman Konsep Matematis Siswa. Jurnal Pendidikan Matematika Universitas Lampung, 1(2).

Ruseffendi, E.T. (1988). Pengantar kepada membantu guru mengembangkan kompetensinya dalam pengajaran matematika untuk meningkatkan CBSA: perkembangan kompetensi guru. Bandung: Tarsito.

Skemp, R.R. (1989). Mathematics in the Primary School. London: Routledge.

Sumarmo, U. (2010). Berpikir dan Disposisi: Apa, mengapa dan bagaimana dikembangkan pada peserta didik. Bandung: Universitas Pendidikan Indonesia (tidak diterbitkan).

Syahlan. (2017). Sepuluh Strategi dalam Pemecahan Masalah Matematika. Indonesian Digital Journal of Mathematics and Education (Idealmathedu), 4 (6) 